\title{
ALKALOIDS FROM LEAVES OF Guatteria pogonopus (ANNONACEAE) AND THEIR CYTOTOXICITIES
}

Maria de Fátima C. Santos ${ }^{\mathrm{a}, \mathrm{b}}$, José Eraldo N. Fontes ${ }^{\mathrm{a}}$, Lívia M. Dutra ${ }^{\mathrm{b}}$, Larissa M. Bomfim ${ }^{\mathrm{c}}$ Cinara O. D. Costa ${ }^{\mathrm{c}}$, Valéria R. S. Moraes $^{\mathrm{a}}$, Andersson Barison ${ }^{\mathrm{b}}$, Milena B. P. Soares ${ }^{\mathrm{c}, \mathrm{d}}$, Felipe Moura A. da Silva ${ }^{\mathrm{e}}$, Jackson R. G. da Silva Almeida ${ }^{\mathrm{f}}$, Héctor H. F. Kooleng, Daniel P. Bezerra ${ }^{\mathrm{b}}$ and Emmanoel Vilaça Costa ${ }^{\mathrm{e}, *}$

${ }^{a}$ Departamento de Química, Universidade Federal de Sergipe, 49100-000 São Cristóvão - SE, Brasil

${ }^{b}$ Centro de Ressonância Magnética Nuclear, Universidade Federal do Paraná, 81530-900 Curitiba - PR, Brasil

'Instituto Gonçalo Moniz, Fundação Oswaldo Cruz, 40296-710 Salvador - BA, Brasil

${ }^{\mathrm{d} C e n t r o ~ d e ~ B i o t e c n o l o g i a ~ e ~ T e r a p i a ~ C e l u l a r, ~ H o s p i t a l ~ S a ̃ o ~ R a f a e l, ~ 41253-190 ~ S a l v a d o r ~-~ B A, ~ B r a s i l ~}$

eDepartamento de Química, Universidade Federal do Amazonas, 69077-000 Manaus - AM, Brasil

${ }^{\mathrm{f}}$ Núcleo de Estudos e Pesquisas de Plantas Medicinais, Universidade Federal do Vale do São Francisco, 56304-205 Petrolina - PE, Brasil

gEscola Superior de Ciências da Saúde, Universidade do Estado do Amazonas, 690065-130 Manaus - AM, Brasil

Recebido em 26/03/2018; aceito em 11/06/2018; publicado na web em 12/07/2018

\begin{abstract}
The phytochemical investigation of the alkaloid-rich fraction obtained from the leaves of Guatteria pogonopus Mart. (Annonaceae) allowed the isolation and identification for the first time in this species of: (+)-nornuciferine (1), a mixture of $\mathbf{1}$ and (+)-anonaine (2), (+)-isocorydine (3), (+)-nuciferine (4), (+)-roemerine (5), (-)-tetrahydropseudocolumbamine (6), a mixture of 6, liriodenine (9) and lysicamine (10), a mixture of 1,2,9-trimethoxy-10-hydroxyaporphine (7) and bulbocapnine (8), 9, 10, and (+)- $N$-methyllindicarpine (11). Compounds $\mathbf{6}, \mathbf{7}, \mathbf{8}$, and $\mathbf{1 1}$ have not been previously reported in the family Annonaceae. Furthermore, the formerly synthetic 1,2,9-trimethoxyaporfin-10-ol (7) is described for the first time as a natural aporphine alkaloid herein. The chemical structures were established by 1D and 2D NMR as well as in comparison with data previously reported in the literature. The cytotoxic activity of the alkaloids was evaluated against tumor (B16-F10, HepG2, HL-60, and K562) and non-tumor (PBMC) cell lines. Alkaloid 1 presented significant activity against $\mathrm{HepG} 2$ cell lines with $\mathrm{IC}_{50}$ of $9.60 \mu \mathrm{mol} \mathrm{L}^{-1}$ while the mixture of $\mathbf{6}, \mathbf{9}$ and $\mathbf{1 0}$ displayed strong cytotoxic activity against $\mathrm{HL}-60$ and $\mathrm{K} 562$ cell lines with $\mathrm{IC}_{50}$ values of 3.41 an $8.50 \mu \mathrm{mol} \mathrm{L} \mathrm{L}^{-1}$, respectively.
\end{abstract}

Keywords: alkaloids; Guatteria pogonopus; leaves; Annonaceae; NMR; cytotoxicity.

\section{INTRODUCTION}

Guatteria (Ruiz \& Pav.) is the largest genus of the family Annonaceae with 307 species of neotropical distribution. ${ }^{1,2}$ In Brazil, about 88 Guatteria species were registered from which, 47 are considered endemic. Among the species of this genera, Guatteria pogonopus Mart. is one of the most widespread, being encountered in the Northeast and Southeastern regions, especially at the Atlantic Forest. This species shows morphological similarities with $G$. oligocarpa and G. ferruginea, although it can be easily identified by the observation of its large glabrous leaves and short pedicel of flowers and fruits. ${ }^{1,2}$

Plants continue to provide diverse and unique compounds with high structural diversity, which in turn are responsible by a wide range of biological activities. Previous works demonstrated a strong cytotoxic activity (in vivo and in vitro) of the essential oil from leaves of $G$. pogonopus against three human tumor cell lines. ${ }^{3}$ These cytotoxic properties were attributed to a synergic effect of the terpenoids in the investigated essential oil. ${ }^{3}$ Another study involving the essential oils of the species $G$. friesiana and G. pogonopus showed relevant trypanocidal and antimalarial activities, which were also attributed to the synergism of the terpenoids. ${ }^{4}$ A study of the chemical constituents of $G$. friesiana essential oil revealed significant antitumor activity and a low systemic activity associated with its $\alpha$-, $\beta$ - and $\gamma$-eudesmol isomers. ${ }^{5}$

In addition, studies involving the isolation of non-volatile

*e-mail: emmanoelvc@gmail.com constituents from G. latifolia revealed a leishmanicidal activity of the alkaloid oxoputerine and antimicrobial action for 9-methoxysomoschatoline, lysicamine, coreximine and isocoreximine. ${ }^{6}$ For $G$. hispida, $O$-methylmoschatoline, lysicamine and liriodenine displayed antiproliferative properties. ${ }^{7}$ Based on this context, species of Guatteria are considered as promising sources of alkaloids with different biological activities.

Currently, only one previous phytochemical study of the alkaloid content of G. pogonopus was reported. ${ }^{8}$ Moving forward in the study of bioactive compounds and their chemotaxonomic significance for the Annonaceae family, we report herein a study displaying the identification of alkaloids from the leaves of G. pogonopus and their cytotoxicity against a panel of tumor cell lines.

\section{EXPERIMENTAL}

\section{General experimental procedures}

Optical rotations were recorded on a Jasco P-2000 polarimeter in $\mathrm{CHCl}_{3}$. 1D and 2D NMR data were acquired at $303 \mathrm{~K}$ in $\mathrm{CDCl}_{3}$ on a Bruker AVANCE III $600 \mathrm{NMR}$ operating at $14.1 \mathrm{~T}$, observing ${ }^{1} \mathrm{H}$ and ${ }^{13} \mathrm{C}$ at 600 and $150 \mathrm{MHz}$, respectively. The NMR spectrometer was equipped with a 5-mm multinuclear inverse detection probe (1D and 2D NMR experiments) with z-gradient. One-bond (HSQC) and long-range (HMBC) ${ }^{1} \mathrm{H}-{ }^{13} \mathrm{C}$ NMR correlation experiments were optimized for average coupling constant ${ }^{1} J_{(\mathrm{C}, \mathrm{H})}$ and ${ }^{\mathrm{LR}} J_{(\mathrm{C}, \mathrm{H})}$ of 140 and $8 \mathrm{~Hz}$, respectively. All ${ }^{1} \mathrm{H}$ and ${ }^{13} \mathrm{C}$ NMR chemical shifts ( $\delta)$ are given in ppm related to the TMS signal at $0.00 \mathrm{ppm}$ as an 
internal reference, and the coupling constants $(J)$ in Hz. ESI-MS spectra were obtained in positive ion detection mode on a Thermo Scientific LTQ XL Linear Ion Trap Mass Spectrometer, equipped with an ESI source. Silica gel 60 (70-230 mesh) was used for the column chromatography (CC), while silica gel $60 \mathrm{~F}_{254}$ (Merck, 0.25 $\mathrm{mm}$, aluminium) was used for analytical $(0.25 \mathrm{~mm})$ and preparative with thin layer chromatography (PTLC) (Merck, $1.00 \mathrm{~mm}$, glass). Compounds were visualized by exposure under UV 254/365 light, by spraying with $p$-anisaldehyde reagent followed by heating on a hot plate, and by spraying Dragendorff's reagent.

\section{Plant material}

Leaves of G. pogonopus were collected in February 2012 at the Park of the Serra of Itabaiana, (geographic coordinates: $09^{\circ} 57^{\prime}$ 54" S and $\left.37^{\circ} 51^{\prime} 46^{\prime \prime} \mathrm{W}\right)$, Sergipe state, Brazil. The material was identified by PhD Ana Paula do Nascimento Prata (a plant taxonomist of the Department of Biology of the Federal University of Sergipe, São Cristovão, SE, Brazil). A voucher specimen (\#24954\#) was deposited at the Herbarium of the Federal University of Sergipe (Herbarium ASE) of the Department of Biology, UFS. The authors had authorization from the Chico Mendes Institute for Biodiversity Conservation from Brazilian Ministry of the Environment for plant collection (number 25637-1). This work was accomplished according to the special authorization for access to genetic resources in Brazil \# 010240/2013-6, issued by CNPq/MCTI.

\section{Extraction and isolation}

Leaves of $G$. pogonopus ( $1.3 \mathrm{~kg}$ ) were dried using an air circulating oven at $45^{\circ} \mathrm{C}$, powdered and successively extracted with hexane $\left(5 \mathrm{~L}, 25^{\circ} \mathrm{C}\right.$, five times) followed by $\mathrm{MeOH}\left(5 \mathrm{~L}, 25^{\circ} \mathrm{C}\right.$, five times), yielding hexane (25.30 g) and $\mathrm{MeOH}(258.60 \mathrm{~g}$ ) extracts after solvent removal under reduced pressure. TLC analysis revealed with Dragendorff's reagent indicated a high concentration of alkaloids in the $\mathrm{MeOH}$ extract. Therefore, an aliquot of the $\mathrm{MeOH}$ extract $(248.60$ g) was submitted to an acid-base extraction to give an alkaloid (3.79 g) and a neutral $(23.81 \mathrm{~g})$ fractions. In this way, part of the alkaloid fraction $(3.70 \mathrm{~g})$ was subjected to silica gel column chromatography (CC) previously treated with an aqueous solution of $\mathrm{NaHCO}_{3}(10 \%$ $v / v)$. Then, the CC was eluted with a gradient system consisting of increasing concentration of $\mathrm{CH}_{2} \mathrm{Cl}_{2}$ in hexane $(95: 5$ to $10: 90, v / v)$, followed by EtOAc in $\mathrm{CH}_{2} \mathrm{Cl}_{2}$ (95:5 to 30:70, v/v) and $\mathrm{MeOH}$ in EtOAc ( $95: 5$ to $50: 50, v / v)$ to afford 274 fractions ( $30 \mathrm{~mL}$ each). The eluted fractions were evaluated and pooled according to TLC analysis yielding 20 distinct groups (GF1-GF20). Group GF3 (397.6 mg) from hexane- $\mathrm{CH}_{2} \mathrm{Cl}_{2}$ (60:40 to $\left.30: 70\right)$ was submitted to a new silica gel $\mathrm{CC}$ eluted with the same eluent system as described for initial $\mathrm{CC}$, to afford 110 fractions $(20 \mathrm{~mL}$ each) that were pooled in fifteen subgroups (GF3.1 to GF3.15) according to TLC analysis. Subgroup GF3.5 was purified by preparative TLC eluted with $\mathrm{CH}_{2} \mathrm{Cl}_{2}: \mathrm{MeOH}$ (95:05, $v / v$, two times) to yield $\mathbf{1}(15.3 \mathrm{mg})$, a mixture of $\mathbf{1}$ and $\mathbf{2}(66.0$ $\mathrm{mg})$ and $3(51.2 \mathrm{mg})$. Group GF4 (342.6 mg) from hexane- $\mathrm{CH}_{2} \mathrm{Cl}_{2}$ (30:70 to 10:90) was also submitted to a new silica gel CC eluted with the same eluent system as described for initial CC, affording 140 fractions (20 mL each). All fractions were analyzed and pooled in sixteen subgroups (GF4.1 to GF4.16), according to TLC analysis. Subgroup GF4.1 (33.7 $\mathrm{mg}$ ) was submitted to a preparative TLC eluted with $\mathrm{CH}_{2} \mathrm{Cl}_{2}: \mathrm{MeOH}$ (95:05, v/v, three times), affording 4 (6.5 $\mathrm{mg}), 5(2.8 \mathrm{mg})$ and $\mathbf{6}(3.0 \mathrm{mg})$. Subgroup GF4.4 (39.9 mg) was purified to a preparative TLC eluted with $\mathrm{CH}_{2} \mathrm{Cl}_{2}: \mathrm{MeOH}(95: 05, v / v$, three times) to yield a mixture of $\mathbf{6 , 9}$ and $\mathbf{1 0}(6.9 \mathrm{mg})$. Subgroup GF4.5 $(11.1 \mathrm{mg})$ when submitted to a preparative TLC eluted with
$\mathrm{CH}_{2} \mathrm{Cl}_{2}: \mathrm{MeOH}(95: 05, v / v$, three times) gave a mixture of $\mathbf{7}$ and $\mathbf{8}$ (2.2 mg). Subgroups GF4.6 (65.1 mg) and GF4.7 (48.1 mg) were also submitted to preparative TLC eluted with the same solvent system (two times) yielding $\mathbf{9}(2.5 \mathrm{mg})$ and $\mathbf{1 0}(3.0 \mathrm{mg})$, and $\mathbf{1 1}(4.1 \mathrm{mg})$, respectively.

(S)-Nornuciferine (1): Brown amorphous powder $\left(\mathrm{CHCl}_{3}\right)$; $[\alpha]_{\mathrm{D}}^{25} 128.5^{\circ}\left(c 0.25, \mathrm{CHCl}_{3}\right)$; identified by comparison with literature da ( ${ }^{1} \mathrm{H}$ NMR and ${ }^{13} \mathrm{C}$ NMR $) .{ }^{9}$

Mixture of nornuciferine and anonaine (2): Brown amorphous powder $\left(\mathrm{CHCl}_{3}\right)$; identified by comparison with literature data ( ${ }^{1} \mathrm{H}$ NMR and ${ }^{13} \mathrm{C}$ NMR) ${ }^{9,10}$

$(S)-(+)$-Isocorydine $(3)$ : Brown amorphous powder $\left(\mathrm{CHCl}_{3}\right)$; $[\alpha]_{\mathrm{D}}{ }^{25} 73.4^{\mathrm{o}}\left(\mathrm{c} 0.14, \mathrm{CHCl}_{3}\right) ;{ }^{1} \mathrm{H}$ and ${ }^{13} \mathrm{C}$ NMR data; see Table 1. ESI-MS $[\mathrm{M}+\mathrm{H}]^{+} \mathrm{m} / \mathrm{z}, 342$.

$(S)$-(+)-Nuciferine (4): Brown amorphous powder $\left(\mathrm{CHCl}_{3}\right)_{;}[\alpha]_{\mathrm{D}}$ ${ }^{25} 23.3^{\circ}$ ( $c 0.46, \mathrm{CHCl}_{3}$ ); ${ }^{1} \mathrm{H}$ and ${ }^{13} \mathrm{C}$ NMR data; see Table 1. ESI-MS $[\mathrm{M}+\mathrm{H}]^{+} m / z, 296$.

$(\mathrm{S})$-(+)-Roemerine (5): Brown amorphous powder $\left(\mathrm{CHCl}_{3}\right)$; $[\alpha]_{\mathrm{D}}{ }^{25} 54.4^{\circ}\left(c 0.18, \mathrm{CHCl}_{3}\right) ;{ }^{1} \mathrm{H}$ and ${ }^{13} \mathrm{C}$ NMR data; see Table 1. ESI-MS $[\mathrm{M}+\mathrm{H}]^{+} m / z, 280$.

$(S)$-(-)-Tetrahydropseudocolumbamine (6): Brown amorphous powder $\left(\mathrm{CHCl}_{3}\right) ;[\alpha]_{\mathrm{D}}{ }^{25}-110.6^{\circ}\left(c 0.19, \mathrm{CHCl}_{3}\right) ;{ }^{1} \mathrm{H}$ and ${ }^{13} \mathrm{C} \mathrm{NMR}$ data; see Table 2. ESI-MS $[\mathrm{M}+\mathrm{H}]^{+} m / z, 342$.

Mixture of 1,2,9-trimethoxy-10-hydroxyaporphine (7) and bulbocapnine (8): Brown amorphous powder $\left(\mathrm{CHCl}_{3}\right) ;{ }^{1} \mathrm{H}$ and ${ }^{13} \mathrm{C}$ NMR data; see Table 3.

Liriodenine (9): Yellow amorphous powder $\left(\mathrm{CHCl}_{3}\right)$; identified by comparison with literature data $\left({ }^{1} \mathrm{H}\right.$ NMR and $\left.{ }^{13} \mathrm{C}\right) .{ }^{11-13}$

Lysicamine (10): Brown amorphous powder $\left(\mathrm{CHCl}_{3}\right)$; identified by comparison with literature data $\left({ }^{1} \mathrm{H}\right.$ NMR and $\left.{ }^{13} \mathrm{C}\right) .{ }^{11,12}$ ESI-MS $[\mathrm{M}+\mathrm{H}]^{+} m / z 292$.

Tetrahydropseudocolumbamine (6), Liriodenine (9), and Lysicamine (10): Orange amorphous powder $\left(\mathrm{CHCl}_{3}\right)$; identified by comparison with literature data $\left({ }^{1} \mathrm{H}\right.$ NMR and ${ }^{13} \mathrm{C}$ NMR $) .{ }^{11,12} \mathrm{EI}-\mathrm{MS}$ $[\mathrm{M}+\mathrm{H}]^{+} \mathrm{m} / \mathrm{z}$ 342, 275 and 292, respectively.

$(\mathrm{S})$-(+)- $\mathrm{N}$-methylindicarpine (11): Brown amorphous powder $\left(\mathrm{CHCl}_{3}\right) ;[\alpha]_{\mathrm{D}}{ }^{25} 152.3^{\circ}$ (c $\left.0.20, \mathrm{CHCl}_{3}\right) ;{ }^{1} \mathrm{H}$ and ${ }^{13} \mathrm{C}$ NMR data; see Table 3 .

\section{Cytotoxicity evaluation}

Cells

Tumor cells lines B16-F10 (mouse melanoma), HepG2 (human hepatocellular carcinoma), K562 (human chronic myelocytic leukemia), and HL-60 (human promyelocytic leukemia) were donated by Hospital A.C. Camargo, São Paulo, SP, Brazil. Cells were maintained in Roswell Park Memorial Institute-1640 (RPMI1640, Gibco-BRL) medium supplemented with $10 \%$ fetal bovine serum (Cultilab), 2 mM L-glutamine (Vetec Química Fina) and $50 \mu \mathrm{g} \mathrm{mL}^{-1}$ gentamycin (Novafarma). Adherent cells were harvested by treatment with $0.25 \%$ trypsin EDTA solution (Gibco-BRL). All cell lines were cultured in cell culture flasks at $37{ }^{\circ} \mathrm{C}$ in $5 \% \mathrm{CO}_{2}$ and sub-cultured every 3-4 days to maintain exponential growth. All experiments were conducted with cells in exponential growth phase. The cell lines were tested for mycoplasma with a Mycoplasma Stain Kit (Sigma-Aldrich) and found to be free from contamination. Heparinized blood (from healthy, 20-35 years old, non-smoker donors who had not taken any drug at least 15 days prior to sampling) was collected and peripheral blood mononuclear cells (PBMC) were isolated by a standard protocol by Ficoll (GE Ficoll-Paque Plus) density gradient centrifugation. PBMC were washed and resuspended at a concentration of $0.3 \times 10^{6}$ cells $\mathrm{mL}^{-1}$ in RPMI 1640 medium 
supplemented with $20 \%$ fetal bovine serum, $2 \mathrm{mmol} \mathrm{L}^{-1}$ glutamine, 50 $\mu \mathrm{g} \mathrm{mL}-1$ gentamycin at $37^{\circ} \mathrm{C}$ with $5 \% \mathrm{CO}_{2}$. In addition, concanavalin A (ConA, Sigma-Aldrich) was used as a mitogen to trigger cell division in T-lymphocytes. ConA $\left(10 \mu \mathrm{g} \mathrm{mL}^{-1}\right)$ was added at the beginning of culture and, after $24 \mathrm{~h}$, cells were treated with the test drugs. The Research Ethics Committee of the Oswaldo Cruz Foundation (Salvador, Bahia, Brazil) approved the experimental protocol (number 031019/2013). All participants signed their written informed consent to participate in the study. For all experiments, cell viability was performed by Trypan Blue Exclusion (TBE) assay. Over $90 \%$ of the cells were viable at the beginning of the culture.

\section{Cytotoxic activity assay}

Cell viability was quantified by alamar blue method, as previously described. ${ }^{14}$ For all experiments, cells were seeded in 96 -well plates $\left(7 \times 10^{4}\right.$ cells $\mathrm{mL}^{-1}$ for adherent cells or $3 \times 10^{5}$ cells $\mathrm{mL}^{-1}$ for suspended cells in $100 \mu \mathrm{L}$ of medium). After $24 \mathrm{~h}$, the compounds $\left(0.19-25 \mu \mathrm{g} \mathrm{mL}{ }^{-1}\right)$ dissolved in dimethyl sulfoxide (DMSO, Sigma-Aldrich) were added to each well and incubated for $72 \mathrm{~h}$. Doxorubicin (purity $\geq 95 \%$, doxorubicin hydrochloride, Laboratory IMA S.A.I.C.) was used as positive control $\left(0.08-5 \mu \mathrm{g} \mathrm{mL}^{-1}\right)$. Negative control received the vehicle used for diluting the tested ( $0.5 \%$ DMSO). Four (for cell lines) or 24 (for PBMC) $\mathrm{h}$ before the end of the incubation, $20 \mu \mathrm{L}$ of stock solution (0.312 $\left.\mathrm{mg} \mathrm{mL}^{-1}\right)$ of the alamar blue (resazurin, Sigma-Aldrich) were added to each well. The absorbance was measured using a SpectraMax 190 multiplate reader and the drug effect was quantified as the percentage of control absorbance at 570 and $600 \mathrm{~nm}$.

\section{Statistical analysis}

Data are presented as half maximal inhibitory concentration $\left(\mathrm{IC}_{50}\right)$ values and their $95 \%$ confidence intervals (CI 95\%) obtained by nonlinear regression. All statistical analyzes were performed using the GraphPad program (Intuitive Software for Science).

\section{RESULTS AND DISCUSSION}

The crude $\mathrm{MeOH}$ extract from the leaves of G. pogonopus displayed cytotoxic activity and was subjected to successive chromatographic procedures allowing the isolation of the alkaloids $(+)$-nornuciferine (1), ${ }^{9}$ anonaine $(2),{ }^{10}(+)$-isocorydine $(3),{ }^{11}(+)$-nuciferine $(4),{ }^{15}$ (+)-roemerine $(\mathbf{5}),{ }^{15}(-)$-tetrahydropseudocolumbamine $(\mathbf{6}),{ }^{16,17}$ 1,2,9-trimethoxy-10-hydroxyaporphine (7), ${ }^{18,19}$ bulbocapnine $(\mathbf{8}),{ }^{20}$ liriodenine (9), ${ }^{11-13}$ lysicamine (10),,${ }^{11,12}$ and (+)- $N$-methyllindicarpine $(\mathbf{1 1})^{21}$ (Figure 1). Compounds 1, 2, 9, and 10 were previously found on the stem barks of this species, ${ }^{8}$ whereas compounds 6-8, and 11 are reported for the first time in Guatteria. Although the structures of the alkaloids $\mathbf{3 - 5},{ }^{11,15} \mathbf{6 - 8},{ }^{16-20}$ and $\mathbf{1 1}^{21}$ have already been described a long time ago, their ${ }^{1} \mathrm{H}$ and ${ }^{13} \mathrm{C}$ data are incomplete or scalar coupling

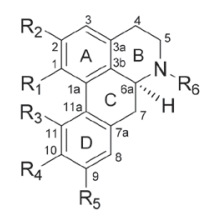

$2 \mathrm{R}_{1}-\mathrm{R}_{2}=\mathrm{OCH}_{2} \mathrm{O} ; \mathrm{R}_{3}=\mathrm{R}_{4}=\mathrm{R}_{5}=\mathrm{R}_{6}=\mathrm{H}$

$3 \mathrm{R}_{1}=\mathrm{R}_{2}=\mathrm{R}_{4}=\mathrm{OCH}_{3} ; \mathrm{R}_{3}=\mathrm{OH} ; \mathrm{R}_{5}=\mathrm{H} ; \mathrm{R}_{6}=\mathrm{CH}_{3}$

$4 \mathrm{R}_{1}=\mathrm{R}_{2}=\mathrm{OCH}_{3} ; \mathrm{R}_{3}=\mathrm{R}_{4}=\mathrm{R}_{5}=\mathrm{H} ; \mathrm{R}_{6}=\mathrm{CH}_{3}$

$5 \mathrm{R}_{1}-\mathrm{R}_{2}=\mathrm{OCH}_{2} \mathrm{O} \cdot \mathrm{R}_{3}=\mathrm{R}_{4}=\mathrm{R}_{5}=\mathrm{H} ; \mathrm{R}_{6}=\mathrm{CH}_{3}$

$7 \mathrm{R}_{1}=\mathrm{R}_{2}=\mathrm{R}_{5}=\mathrm{OCH}_{3} ; \mathrm{R}_{3}=\mathrm{H} ; \mathrm{R}_{4}=\mathrm{OH} ; \mathrm{R}_{5}=\mathrm{H} ; \mathrm{R}_{6}=\mathrm{CH}_{3}$

$8 \mathrm{R}_{1}-\mathrm{R}_{2}=\mathrm{OCH}_{2} \mathrm{O} ; \mathrm{R}_{3}=\mathrm{OH} ; \mathrm{R}_{4}=\mathrm{OCH}_{3} ; \mathrm{R}_{5}=\mathrm{H} ; \mathrm{R}_{6}=\mathrm{CH}_{3}$

$11 \mathrm{R}_{1}=O \mathrm{CH}_{3} ; \mathrm{R}_{2}=\mathrm{R}_{3}=\mathrm{OH} ; \mathrm{R}_{4}=\mathrm{OCH}_{3} ; \mathrm{R}_{5}=\mathrm{H} ; \mathrm{R}_{6}=\mathrm{CH}_{3}$
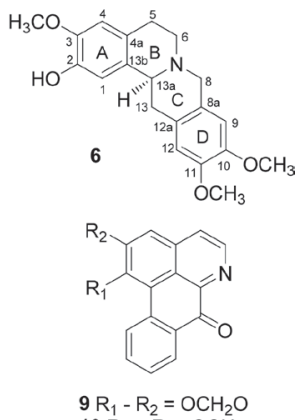

$9 \mathrm{R}_{1}-\mathrm{R}_{2}=\mathrm{OCH}_{2} \mathrm{O}$
$10 \mathrm{R}_{1}=\mathrm{R}_{2}=\mathrm{OCH}_{3}$
$1 \mathrm{R}_{1}=\mathrm{R}_{2}=\mathrm{OCH}_{3} ; \mathrm{R}_{3}=\mathrm{R}_{4}=\mathrm{R}_{5}=\mathrm{R}_{6}=\mathrm{H}$

Figure 1. Alkaloids isolated from leaves of Guatteria pogonopus constants values have not been assigned and/or obtained. In this work, the complete and unequivocal ${ }^{1} \mathrm{H}$ and ${ }^{13} \mathrm{C}$ data were reviewed according to $1 \mathrm{D}$ and 2D NMR experiments.

The ${ }^{1} \mathrm{H}$ NMR spectrum of compound $\mathbf{3}$ revealed the presence of two spin systems, one consisting of the signals at $\delta 3.19(1 \mathrm{H}, d d d$, $J=16.3,12.0$ and $6.0 \mathrm{~Hz}, \mathrm{H}-4$ pseudoequatorial $)$ and $\delta 2.72(1 \mathrm{H}$, $d d d, J=16.3,13.3$ and $3.9 \mathrm{~Hz}, \mathrm{H}-4$ pseudoaxial), as well as $\delta 3.04$ $(1 \mathrm{H}, d d d, J=15.7,13.3$ and $6.0 \mathrm{~Hz}, \mathrm{H}-5$ pseudoequatorial) and $\delta 2.49(1 \mathrm{H}, d d d, J=15.7,12.0$ and $3.9 \mathrm{~Hz}, \mathrm{H}-5$ pseudoaxial $)$ and the other comprising the signals at $\delta 3.04(1 \mathrm{H}, m, \mathrm{H}-6 \mathrm{a}), 2.89(1 \mathrm{H}, d$, $J=12.7 \mathrm{~Hz}, \mathrm{H}-7$ pseudoequatorial $)$, and $\delta 2.45(1 \mathrm{H}, d, J=12.7 \mathrm{~Hz}$, $\mathrm{H}-7$ pseudoaxial). The singlet at $\delta 2.54(3 \mathrm{H})$ revealed the presence of an $\mathrm{N}-\mathrm{CH}_{3}$ group. Furthermore, it was observed a singlet at $\delta 6.70$ $(1 \mathrm{H}, \mathrm{H}-3)$, indicative of an 1,2,3,4,5-pentasubstituted benzene ring, as well as a spin system at $\delta 6.83(1 \mathrm{H}, d, J=8.1 \mathrm{~Hz}, \mathrm{H}-8)$ and 6.86 $(1 \mathrm{H}, d, J=8.1 \mathrm{~Hz}, \mathrm{H}-9)$, confirming the presence a disubstituted benzene ring. The signals at $\delta 3.70,3.91$ and 3.92 (each, $3 \mathrm{H}, s$ ) were assigned to three methoxyl groups. The location of the methoxyl groups were established based on the long-range ${ }^{1} \mathrm{H}-{ }^{13} \mathrm{C}$ correlation map from HMBC NMR experiment (Table 1 and Figure 2). This analysis revealed that the hydrogen at $\delta 6.70(\mathrm{H}-3)$ had long-range ${ }^{1} \mathrm{H}-{ }^{13} \mathrm{C}$ correlation with the carbons $\delta 142.3(\mathrm{C}-1), 151.4(\mathrm{C}-2), 129.2$ (C-3b), and 29.3 (C-4). In contrast, the hydrogen at $\delta 6.83(\mathrm{H}-8)$ showed correlation with carbon at $\delta 35.9$ (C-7), 120.3 (C-11a) and 149.6 (C-10). The presence of a hydroxyl group in the molecule located in the $\mathrm{D}$ ring at $\mathrm{C}-10$ was established on the basis of long-range ${ }^{1} \mathrm{H}-{ }^{13} \mathrm{C}$ correlation of the hydrogen at $\delta 6.86(\mathrm{H}-9)$ with the carbon $\delta 144.2$ (C-11), which showed no correlation with the methoxyl group. Therefore, based on these NMR data, compound $\mathbf{3}$ was established as the aporphine alkaloid, (+)-isocorydine. This compound has been found in species of Annonaceae, such as G. oliviformis, ${ }^{22}$ G. tonduzii, ${ }^{22}$ Enantia polycarpa, ${ }^{23}$ and Gonothalamus tamirensis. ${ }^{24}$

The ${ }^{1} \mathrm{H}$ NMR spectrum of compound 4 revealed the presence of two spin systems, one consisting of the signals at $\delta 3.19(1 \mathrm{H}, d d d$, $J=16.3,12.3$ and $5.8 \mathrm{~Hz}, \mathrm{H}-4$ pseudoequatorial $)$ and $\delta 2.69(1 \mathrm{H}$, $d d d, J=16.3,12.6,3.5 \mathrm{~Hz}, \mathrm{H}-4$ pseudoaxial $)$ as well as $\delta 3.10(1 \mathrm{H}$, $d d d, J=15.4,12.6,5.8 \mathrm{~Hz}, \mathrm{H}-5$ pseudoequatorial) and $2.55(1 \mathrm{H}, d d d$, $J=15.4,12.3,3.5 \mathrm{~Hz}, \mathrm{H}-5$ pseudoaxial), and the other comprising the signals at $\delta 3.08(1 \mathrm{H}, m, \mathrm{H}-6 \mathrm{a}), \delta 3.09(1 \mathrm{H}, d d, J=14.3$ and $3.9 \mathrm{~Hz}, \mathrm{H}-7$ pseudoequatorial) and $2.65(1 \mathrm{H}, d, J=14.3 \mathrm{~Hz}, \mathrm{H}-7$ pseudoaxial). Similarly, to compound 3, the presence of an $\mathrm{N}-\mathrm{CH}_{3}$ group was observed, due to the singlet at $\delta 2.58(3 \mathrm{H})$ with correlations in the HMBC map with the carbons at $\delta 53.2$ (C-5) and 62.3 (C-6a). By analysis of the ${ }^{1} \mathrm{H}$ NMR spectrum it was also possible to observe the presence of a singlet at $\delta 6.63(1 \mathrm{H}, \mathrm{H}-3)$. The main difference between $\mathbf{4}$ and $\mathbf{3}$ is the absence of substituents at ring $\mathrm{D}$. The hydrogen $\mathrm{H}-3$ showed long-range ${ }^{1} \mathrm{H}-{ }^{13} \mathrm{C}$ correlation with the carbons $\delta 145.3$ (C-1), 152.1 (C-2), 126.9 (C-3b), and 28.9 (C-4) (Figure 2). On the other hand, a second difference between $\mathbf{4}$ and $\mathbf{3}$ was the absence of substitution at the D ring (Table 1). According with ${ }^{1} \mathrm{H}$ and ${ }^{13} \mathrm{C} \mathrm{NMR}$ 1D/2D data, compound 4 was identified as the aporphine alkaloid, (+)-nuciferine. This compound has been found only in Annonaceae species, such as in G. ouregou. ${ }^{25}$

Compound 5 presented ${ }^{1} \mathrm{H}$ NMR spectrum very similar to those of 4. The main difference is the presence of methylenedioxy group in the A ring due to the observation of dublets at $\delta 6.08$ and 5.93 (each, $1 \mathrm{H}, d$, $J=1.4 \mathrm{~Hz}, \mathrm{H}-1$ and $\mathrm{H}-2$ ). The location of the methylenedioxy group at $\mathrm{C}-1$ and $\mathrm{C}-2$ was confirmed based on the long-range ${ }^{1} \mathrm{H}-{ }^{13} \mathrm{C}$ correlation map from HMBC NMR experiment. In this, the signal at $\delta 6.56$ $(\mathrm{H}-3, s)$ showed long-range ${ }^{1} \mathrm{H}-{ }^{13} \mathrm{C}$ correlation with carbons $\delta 142.9$ (C-1), 147.2 (C-2), 127.0 (C-3a), and 29.3 (C-4) (Table 1 and Figure 2). According with ${ }^{1} \mathrm{H}$ and ${ }^{13} \mathrm{C}$ NMR $1 \mathrm{D} / 2 \mathrm{D}$ data, compound 5 was identified as the aporphine alkaloid, (+)-roemerine. This compound 
Table 1. NMR data (600 and $150 \mathrm{MHz}$ for ${ }^{1} \mathrm{H}$ and ${ }^{13} \mathrm{C}$, respectively) for the aporphine alkaloids 3,4 and 5

\begin{tabular}{|c|c|c|c|c|c|c|}
\hline \multirow{2}{*}{ Position } & \multicolumn{2}{|r|}{3} & \multicolumn{2}{|r|}{4} & \multicolumn{2}{|r|}{5} \\
\hline & $\delta_{\mathrm{C}}$ mult. $^{\mathrm{a}, \mathrm{b}}$ & $\delta_{\mathrm{H}}$ mult. $(J \text { in } \mathrm{Hz})^{\mathrm{a}}$ & $\delta_{\mathrm{C}}$ mult. $^{\mathrm{a}, \mathrm{b}}$ & $\delta_{\mathrm{H}}$ mult. $(J \text { in } \mathrm{Hz})^{\mathrm{a}}$ & $\delta_{\mathrm{C}}$ mult. $^{\mathrm{a}, \mathrm{b}}$ & $\delta_{\mathrm{H}}$ mult. $(J \text { in } \mathrm{Hz})^{\mathrm{a}}$ \\
\hline 1 & 142.3 & & 145.3 & & 142.9 & \\
\hline $1 \mathrm{a}$ & 126.0 & & 110.6 & & 116.4 & \\
\hline 2 & 151.4 & & 152.1 & & 147.2 & \\
\hline 3 & 111.2 & $6.70 s$ & 111.4 & $6.63 s$ & 107.7 & $6.56 s$ \\
\hline $3 a$ & 129.2 & & 128.4 & & 123.5 & \\
\hline $3 b$ & 130.0 & & 126.9 & & 127.0 & \\
\hline $4_{\text {pseudoequatorial }}$ & 29.3 & $3.19 d d d(16.3 ; 12.0 ; 6.0)$ & 28.9 & $3.19 d d d(16.3 ; 12.3 ; 5.8)$ & 29.3 & $3.16 m$ \\
\hline $4_{\text {pseudoaxial }}$ & & $2.72 d d d(16.3 ; 13.3 ; 3.9)$ & & $2.69 d d d(16.3 ; 12.6 ; 3.5)$ & & $2.66 \mathrm{~m}$ \\
\hline $5_{\text {pseudoequatorial }}$ & 52.8 & $3.04 d d(15.7 ; 13.3 ; 6.0)$ & 53.2 & $3.10 d d d(15.4 ; 12.6 ; 5.8)$ & 53.5 & $3.11 \mathrm{~m}$ \\
\hline $5_{\text {pseudoaxial }}$ & & $2.49 \mathrm{dd}(15.7 ; 12.0 ; 3.9)$ & & $2.55 d d d(15.4 ; 12.3 ; 3.5)$ & & $2.58 \mathrm{~m}$ \\
\hline $6 a$ & 62.9 & $3.04 \mathrm{~m}$ & 62.3 & $3.08 \mathrm{~m}$ & 61.9 & $3.67 \mathrm{~m}$ \\
\hline $7_{\text {pseudoequatorial }}$ & 35.9 & $2.89 d(12.7)$ & 34.8 & $3.09 d d(14.3 ; 3.9)$ & 34.4 & $3.17 d d(14.0 ; 3.8)$ \\
\hline $7_{\text {pseudoaxial }}$ & & $2.45 d(12.7)$ & & $2.65 d(14.3)$ & & $2.75 \mathrm{~m}$ \\
\hline $7 \mathrm{a}$ & 130.2 & & 136.2 & & 135.2 & \\
\hline 8 & 119.0 & $6.83 d(8.1)$ & 127.9 & $7.25 d d(8.7 ; 1.2)$ & 128.2 & $7.26 \mathrm{~m}$ \\
\hline 9 & 111.3 & $6.86 d(8.1)$ & 127.4 & $7.23 d d d(8.7 ; 7.3 ; 1.3)$ & 127.6 & $7.23 d d(7.2 ; 1.2)$ \\
\hline 10 & 149.6 & & 127.0 & $7.30 d d d(7.8 ; 7.3 ; 1.2)$ & 127.3 & $7.31 d d d(7.7 ; 7.2 ; 1.0)$ \\
\hline 11 & 144.2 & & 128.9 & $8.35 d d(7.8 ; 1.3)$ & 127.2 & $8.06 d d(7.7 ; 1.2)$ \\
\hline $11 \mathrm{a}$ & 120.3 & & 132.1 & & 131.2 & \\
\hline $\mathrm{H}_{3} \mathrm{C}-N$ & 43.9 & $2.54 s$ & 43.7 & $2.58 \mathrm{~s}$ & 43.6 & $2.60 s$ \\
\hline $\mathrm{H}_{3} \mathrm{CO}-1$ & 62.1 & $3.70 s$ & 60.3 & $3.65 s$ & & \\
\hline $\mathrm{H}_{3} \mathrm{CO}-2$ & 56.0 & $3.91 s$ & 55.9 & $3.88 s$ & & \\
\hline $\mathrm{H}_{3} \mathrm{CO}-10$ & 56.3 & $3.92 s$ & & & & \\
\hline HO-11 & & $8.81 s$ & & & & \\
\hline $1-\mathrm{OCH}_{2} \mathrm{O}-2$ & & & & & 101.0 & $\begin{array}{l}6.08 d(1.4) \\
5.93 d(1.4)\end{array}$ \\
\hline
\end{tabular}

${ }^{\mathrm{a}} \mathrm{NMR}$ experiments were acquired at $303 \mathrm{~K}$ with TMS as internal reference at $0.00 \mathrm{ppm}$ in $\mathrm{CDCl}_{3} .{ }^{\mathrm{b}}$ Multiplicities determined by DEPT 135 , $\mathrm{HSQC}$ and $\mathrm{HMBC}$ experiments.

has been found in species of Annonaceae such as in Gonothalamus tamirensis, ${ }^{24}$ Guatteria sagotiana, ${ }^{26}$ and Xylopia laevigata. ${ }^{27}$

Compound 6 showed several signals in the aliphatic region of ${ }^{1} \mathrm{H}$ NMR spectrum that along with ${ }^{1} \mathrm{H}-{ }^{1} \mathrm{H}$ correlations of the COSY map revealed four spin systems, which are typical for tetrahydropseudoprotoberberine alkaloids (Table 2). The three singlets at $\delta 3.84,3.85$ and $3.87(3 \mathrm{H}$, each) indicated the presence of three methoxyl groups in the structure. The complete assignments of the ${ }^{1} \mathrm{H}$ and ${ }^{13} \mathrm{C}\left\{{ }^{1} \mathrm{H}\right\}$ NMR chemical shifts were established based on one-bond and long-range ${ }^{1} \mathrm{H}-{ }^{13} \mathrm{C}$ correlation map from HSQC and HMBC experiments (Figure 2). The hydrogen at $\delta 6.82$ showed long-range ${ }^{1} \mathrm{H}^{-13} \mathrm{C}$ correlation with the carbons at $\delta 59.5$ (C-13a), $126.0(\mathrm{C}-4 \mathrm{a})$ and $145.1(\mathrm{C}-3)$, as well as, the signal at $\delta 6.59(\mathrm{H}-4)$, which displayed long-range ${ }^{1} \mathrm{H}-{ }^{13} \mathrm{C}$ correlation with the carbons at $\delta 29.0$ (C-5), 130.7 (C-13b) and 144.1 (C-2). The hydroxyl group at $\mathrm{C}-2$ was confirmed based on the long-range ${ }^{1} \mathrm{H}^{13} \mathrm{C}$ correlation of the hydrogen at $\delta 6.59(\mathrm{H}-4)$ with the carbon at $\delta 144.1(\mathrm{C}-2)$. This signal did not show any correlation with the methoxyl group. However, the singlet at $\delta 3.87$ showed long-range correlation with the carbon at $\delta 145.1(\mathrm{C}-3)$, confirming the methoxyl group at A ring (Table 2). These findings suggest the presence the tetrasubstituted benzene ring. On the other hand, the singlet at $\delta 6.56(\mathrm{H}-8)$ showed long-range ${ }^{1} \mathrm{H}-{ }^{13} \mathrm{C}$ correlation with the carbons at $\delta 58.3(\mathrm{C}-7), 126.4$ (C-12) and 147.8 (C-10), as well as the signal at $\delta 6.64$ (H-11), which showed long-range ${ }^{1} \mathrm{H}-{ }^{13} \mathrm{C}$ correlation with the carbons at $\delta 36.3$ (C-12a), 126.2 (C-8a) and 147.5 (C-9). The methoxyl hydrogens at $\delta 3.84$ and 3.85 displayed long-range ${ }^{1} \mathrm{H}-{ }^{13} \mathrm{C}$ correlations with the carbons $\delta 147.5$ and 147.8 , respectively. Thus, data suggest the existence of a system tetrasubstituted at $\mathrm{D}$ ring of this alkaloid. Based on the ${ }^{1} \mathrm{H}$ and ${ }^{13} \mathrm{C}$ NMR 1D/2D data, compound 6 was identified as being a 2,3,10,11-tetrahydropseudoprotoberberine alkaloid known as (-)-tetrahydropseudocolumbamine. This compound was found for first time in Guatteria. Previously, this compound has been reported only in Chasmanthera dependens ${ }^{16}$ and Isopyrum thalictroide. ${ }^{17}$

Compounds $\mathbf{7}$ and $\mathbf{8}$ were obtained in mixture, once its NMR data indicated the presence of two set of signals with different ratios. The first set of signals in the ${ }^{1} \mathrm{H}$ NMR spectrum displayed two spin system characteristics of aporphine alkaloids at $\delta 3.16$ and $\delta 2.68(1 \mathrm{H}$ each, $m, \mathrm{H}-4)$ and $\delta 3.03$ and 2.49 (1H each, $m, \mathrm{H}-5)$, and the other, with the signals at $\delta 2.98(1 \mathrm{H}, m, \mathrm{H}-6 \mathrm{a})$, and $\delta 3.07$ and $\delta 2.48$ (1H each, $m$, $\mathrm{H}-7)$. The signal at $\delta 2.54(3 \mathrm{H}, s)$ revealed the presence of an $\mathrm{N}-\mathrm{CH}_{3}$ group. The singlet at $\delta 6.69(1 \mathrm{H}, \mathrm{H}-3)$ indicated a tetrasubstituted benzene ring and the spin system at $\delta 6.83(1 \mathrm{H}, s, \mathrm{H}-8)$ and $\delta 8.80(1 \mathrm{H}$, $s, \mathrm{H}-11)$ indicating a $p$-substituted benzene ring. The location of the 
Table 2. NMR data (600 and $150 \mathrm{MHz}$ for ${ }^{1} \mathrm{H}$ and ${ }^{13} \mathrm{C}$, respectively) for tetrahydropseudoprotoberberine alkaloid 6

\begin{tabular}{|c|c|c|}
\hline \multirow{2}{*}{ Position } & \multicolumn{2}{|r|}{6} \\
\hline & $\delta_{\mathrm{C}}$ mult $^{\mathrm{a}, \mathrm{ab}}$ & $\delta_{\mathrm{H}}$ mult. $(J \text { in } \mathrm{Hz})^{\mathrm{a}, \mathrm{b}}$ \\
\hline 1 & 111.3 & $6.82 s$ \\
\hline 2 & 144.1 & \\
\hline 3 & 145.1 & \\
\hline 4 & 110.6 & $6.59 s$ \\
\hline $4 a$ & 126.0 & \\
\hline $5_{\text {pseudoaxial }}$ & 29.0 & $2.67 \mathrm{~m}$ \\
\hline $5_{\text {pseudoequatorial }}$ & & $3.16 \mathrm{~m}$ \\
\hline $6_{\text {pseudoaxial }}$ & 51.5 & $2.62 \mathrm{~m}$ \\
\hline $6_{\text {pseudoequatorial }}$ & & $3.14 \mathrm{~m}$ \\
\hline $7_{\text {pseudoaxial }}$ & 58.3 & $3.67 d(14.5)$ \\
\hline $7_{\text {pseudoaequatorial }}$ & & $3.94 d(14.5)$ \\
\hline $7 \mathrm{a}$ & 126.2 & \\
\hline 8 & 109.5 & $6.56(1 \mathrm{H}, s)$ \\
\hline 9 & 147.5 & \\
\hline 10 & 147.8 & \\
\hline 11 & 111.5 & $6.65(1 \mathrm{H}, s)$ \\
\hline 12 & 126.4 & \\
\hline $12 \mathrm{a}_{\text {pseudoaxial }}$ & 36.3 & $3.22(1 \mathrm{H}, d d, 16.0$ e 3.7$)$ \\
\hline $12 \mathrm{a}_{\text {pseudoequatorial }}$ & & $2.83(1 \mathrm{H}, d d, 16.0 \mathrm{e} 11.4)$ \\
\hline $13 \mathrm{a}$ & 59.5 & $3.57(1 \mathrm{H}, m)$ \\
\hline $13 b$ & 130.7 & \\
\hline $\mathrm{H}_{3} \mathrm{CO}-3$ & 55.9 & $3.87(3 \mathrm{H}, s)$ \\
\hline $\mathrm{H}_{3} \mathrm{CO}-9$ & 55.9 & $3.84(3 \mathrm{H}, s)$ \\
\hline $\mathrm{H}_{3} \mathrm{CO}-10$ & 56.0 & $3.85(3 \mathrm{H}, s)$ \\
\hline
\end{tabular}

${ }^{a} \mathrm{NMR}$ experiments were acquired at $303 \mathrm{~K}$ with TMS as internal reference at $0.00 \mathrm{ppm}$ in $\mathrm{CDCl}_{3}$. ${ }^{\mathrm{b}}$ Multiplicities determined by DEPT 135, HSQC and HMBC experiments.

methoxyl groups C-1, C-2 and C-9 were established based on the longrange ${ }^{1} \mathrm{H}_{-}{ }^{13} \mathrm{C}$ correlations of the $\mathrm{HMBC}$ map. In this, the hydrogen at $\delta 6.69(\mathrm{H}-3)$ showed long-range ${ }^{1} \mathrm{H}-{ }^{13} \mathrm{C}$ correlation with the carbons at $\delta 142.3$ (C-1), 151.3 (C-2), 129.0 (C-3b), and 29.3 (C-4). On the other hand, the hydrogen at $\delta 8.80(\mathrm{H}-11)$ showed long-range ${ }^{1} \mathrm{H}-{ }^{13} \mathrm{C}$ correlation with carbons at $\delta 103.4$ (C-1a), 120.1 (C-7a), and 149.5 (C-9). The hydroxyl group at $\mathrm{C}-10$ was established based on the long-range ${ }^{1} \mathrm{H}-{ }^{13} \mathrm{C}$ correlation of hydrogen at $\delta 6.83(\mathrm{H}-8)$ with the carbon at $\delta 144.0(\mathrm{C}-10)$ that showed no correlation with hydrogens from methoxyl group. The overall analysis of 1D and 2D NMR experiments enabled the complete and unequivocal ${ }^{1} \mathrm{H}$ and ${ }^{13} \mathrm{C} N M R$ chemical shifts assignments (Table 3 and Figure 2). Considering the ${ }^{1} \mathrm{H}$ and ${ }^{13} \mathrm{C}$ NMR $1 \mathrm{D} / 2 \mathrm{D}$ data, compound 7 was identified as 1,2,9-trimethoxy-10-hydroxyaporphine. This compound was only obtained by synthesis and is being reported in this communication as a natural product for the first time..$^{18,19}$

The second NMR dataset in the ${ }^{1} \mathrm{H}$ NMR showed similar spins systems for compound 7. However, in this case the methoxyl group signals were replaced by signals that suggested the presence of a methylenedioxy bridge between $\mathrm{C}-1$ and $\mathrm{C}-2$, which was confirmed based on the long-range ${ }^{1} \mathrm{H}-{ }^{13} \mathrm{C}$ correlation map from HMBC NMR experiment. The singlet at $\delta 6.63(\mathrm{H}-3)$, as well as the doublets at $\delta 5.95$ and 6.10 of the methylenedioxy bridge hydrogens showed long-range ${ }^{1} \mathrm{H}-{ }^{13} \mathrm{C}$ correlation with carbons at $\delta 140.5(\mathrm{C}-1)$ and 145.9 (C-2) (Table 3). Furthermore, the doublets at $\delta 6.82(\mathrm{H}-8$, $J=8.1 \mathrm{~Hz})$ and $6.86(\mathrm{H}-9, J=8.1 \mathrm{~Hz})$ indicated a tetrasubstituted benzene ring. The methoxyl group at $\mathrm{C}-10$ was established based on the long-range ${ }^{1} \mathrm{H}-{ }^{13} \mathrm{C}$ correlation of hydrogen at $\delta 6.82(\mathrm{H}-8)$ with the carbon at $\delta 148.5$ (C-10). The hydroxyl group at C-11 was established on the basis of the long-range ${ }^{1} \mathrm{H}-{ }^{13} \mathrm{C}$ correlation of hydrogen at $\delta 6.86$ (H-9) with the carbon at $\delta 144.2$ (C-11) that showed no correlation with hydrogens from methoxyl group. The overall analysis of 1D and 2D NMR experiments enabled the complete and unequivocal ${ }^{1} \mathrm{H}$ and ${ }^{13} \mathrm{C}$ NMR chemical shifts assignments (Table 3 and Figure 2). Based on ${ }^{1} \mathrm{H}$ and ${ }^{13} \mathrm{C}$ NMR $1 \mathrm{D} / 2 \mathrm{D}$ data, compound 8 was identified as bulbocapnine. This compound was found for the first time in Guatteria. This compound has been previously found in Menispermaceae species, such as Antizoma miersiana. ${ }^{20}$

Compound 11 displayed two spin systems in the ${ }^{1} \mathrm{H}$ NMR spectrum, which are characteristic of an aporphine alkaloid, one consisting of the signals at $\delta 3.16$ and $\delta 2.69(1 \mathrm{H} \mathrm{each,} m, \mathrm{H}-4)$ and $\delta 3.05$ and 2.54 ( $1 \mathrm{H}$ each, $m, \mathrm{H}-5)$, and the other comprising the signals at $\delta 2.94(1 \mathrm{H}, m, \mathrm{H}-6 \mathrm{a})$, and $\delta 3.05$ and $2.52(1 \mathrm{H}, m, \mathrm{H}-7$, respectively). The signal at $\delta 2.57(3 \mathrm{H}, \mathrm{s})$ was indicative of an $\mathrm{N}-\mathrm{CH}_{3}$ group. A singlet at $\delta 6.78(1 \mathrm{H}, \mathrm{H}-3)$ indicated a pentasubstituted benzene ring and the spin system at $\delta 6.84(1 \mathrm{H}, d, J=8.1 \mathrm{~Hz}, \mathrm{H}-8)$ and $6.86(1 \mathrm{H}, d, J=8.1 \mathrm{~Hz}, \mathrm{H}-9)$, indicating a tetrasubstituted benzene ring. The location of the methoxyl groups at C-1 and C-10, as well as hydroxyl substituents at $\mathrm{C}-2$ and $\mathrm{C}-11$ were established based on the long-range ${ }^{1} \mathrm{H}-{ }^{13} \mathrm{C}$ correlations from the HMBC map (Table 3 and Figure 2). The hydrogen at $\delta 6.78(\mathrm{H}-3)$ showed long-range ${ }^{1} \mathrm{H}-{ }^{13} \mathrm{C}$ correlation with the carbon at $\delta 140.6(\mathrm{C}-1)$ which showed correlation hydrogens from the methoxyl group, as well as, the hydrogen at $\delta 6.84(\mathrm{H}-8, d, J=8.1 \mathrm{~Hz})$ showed long-range ${ }^{1} \mathrm{H}-{ }^{13} \mathrm{C}$ correlation with the carbon at $\delta 149.1$ (C-10) revealed correlation with hydrogens from the methoxyl group. The hydroxyl group was established based on the long-range ${ }^{1} \mathrm{H}^{13} \mathrm{C}$ correlation of hydrogen at $\delta 6.86(\mathrm{H}-9, d, J=8.1 \mathrm{~Hz})$ with the carbon at $\delta 143.7(\mathrm{C}-11)$ that showed no correlation with hydrogens from the methoxyl group. Using the ${ }^{1} \mathrm{H}$ and ${ }^{13} \mathrm{C}$ NMR $1 \mathrm{D} / 2 \mathrm{D}$ data, compound 11 was identified as (+)-N-methyllindicarpine. This compound was found for first time in Guatteria, although it has been found in species of the Papaveraceae family, such as Glacium vittelium. ${ }^{28}$

The cytotoxic activity of the isolated alkaloids was evaluated against tumor (B16-F10, HepG2, HL-60, and K562) and non-tumor (PBMC) cell lines (Table 4) using the Alamar blue assay after $72 \mathrm{~h}$ of incubation. Alkaloids $\mathbf{1}, \mathbf{3}, \mathbf{4}$, and $\mathbf{5}$, and the mixture of $\mathbf{6 , 9}$ and 10 displayed moderate cytotoxic effects when compared to the positive control doxorubicin. In fact, some of these alkaloids have been previously reported as cytotoxic agents. ${ }^{27,29-31}$ Moreover, the cytotoxicity of the mixture $\mathbf{6 , 9}$ and $\mathbf{1 0}$ may due to the presence of the compound $\mathbf{9}$, which has reported with a potent cytotoxic activity. ${ }^{31}$

Among the alkaloids evaluated, (+)-nornuciferine (1), and the mixture of $\mathbf{6 , 9}$ and $\mathbf{1 0}$ displayed promising cytotoxicity activities with $\mathrm{IC}_{50}$ values below to $17.0 \mu \mathrm{mol} \mathrm{L} \mathrm{L}^{-1}$ against HepG2, HL and K562. However, (+)-nornuciferine showed significant activity against HepG2 with $\mathrm{IC}_{50}$ value of $9.60 \mu \mathrm{mol} \mathrm{L}^{-1}$ while the mixture of $\mathbf{6 , 9}$ and 10 demonstrated strong activity against HL-60 and K562 tumor cell lines with $\mathrm{IC}_{50}$ values of 3.41 and $8.50 \mu \mathrm{mol} \mathrm{L}^{-1}$ (Table 4). The results obtained were in accordance with Menezes et al. ${ }^{27}$ that reported the cytotoxic activity of several aporphine and tetrahydroprotoberberine alkaloids. Alkaloids $\mathbf{6}\left(\mathrm{IC}_{50}>73.23 \mu \mathrm{mol} / \mathrm{L}\right), \mathbf{1 1}\left(\mathrm{IC}_{50}>76.36 \mu \mathrm{mol} \mathrm{L}-1\right)$ and the mixture of $\mathbf{7}$ and $\mathbf{8}\left(\mathrm{IC}_{50}>36.72 \mu \mathrm{mol} \mathrm{L} \mathrm{L}^{-1}\right)$ were considered inactive in any tumor cell lines tested (Table 4). The selectivity indexes (SI, SI $\left.=\mathrm{IC}_{50}[\mathrm{PBMC}] / \mathrm{IC}_{50}[\mathrm{HL}-60]\right)$ of $\mathbf{1 , 3}, \mathbf{4}$, and $\mathbf{5}$ and the mixture of $\mathbf{6 , 9}$ and $\mathbf{1 0}$, were $2.7,1.1,2.0,2.1$, and 9.8 , respectively, 
Table 3. NMR data (600 and $150 \mathrm{MHz}$ for ${ }^{1} \mathrm{H}$ and ${ }^{13} \mathrm{C}$, respectively) for aporphine alkaloids 7, 8 and 11

\begin{tabular}{|c|c|c|c|c|c|c|}
\hline \multirow{2}{*}{ Position } & \multicolumn{2}{|r|}{7} & \multicolumn{2}{|c|}{8} & \multicolumn{2}{|c|}{11} \\
\hline & $\delta_{\mathrm{C}}$ mult $^{\mathrm{a}}$ & $\delta_{\mathrm{H}}$ mult. $(J \text { in } \mathrm{Hz})^{\mathrm{a}}$ & $\delta_{\mathrm{C}}$ mult $^{\mathrm{a}}$ & $\delta_{\mathrm{H}}$ mult. $(J \text { in } \mathrm{Hz})^{\mathrm{a}}$ & $\delta_{\mathrm{C}}$ mult $^{\mathrm{a}}$ & $\delta_{\mathrm{H}}$ mult. $(\mathrm{J} \text { in } \mathrm{Hz})^{\mathrm{a}}$ \\
\hline 1 & 142.3 & & 140.5 & & 140.6 & \\
\hline 1a & 103.4 & & N.O & & 124.6 & \\
\hline 2 & 151.3 & & 145.9 & & 147.6 & \\
\hline 3 & 111.2 & $6.69 s$ & 107.7 & $6.63 s$ & 114.6 & $6.78 s$ \\
\hline $3 a$ & 129.3 & & & & 130.1 & \\
\hline $3 b$ & 129.0 & & 128.8 & & 128.4 & \\
\hline $4_{\text {pseudoequatorial }}$ & 29.3 & $3.16 m$ & 29.0 & $3.13 \mathrm{~m}$ & 28.6 & $3.16 m$ \\
\hline $4_{\text {pseudoaxial }}$ & & $2.68 \mathrm{~m}$ & & $2.66 m$ & & $2.69 \mathrm{~m}$ \\
\hline $5_{\text {pseudoequatorial }}$ & 52.9 & $3.03 \mathrm{~m}$ & 53.0 & $3.07 \mathrm{~m}$ & 52.7 & $3.05 \mathrm{~m}$ \\
\hline $5_{\text {pseudoaxial }}$ & & $2.49 m$ & & $2.45 \mathrm{~m}$ & & $2.54 m$ \\
\hline $6 a$ & 62.6 & $2.98 \mathrm{~m}$ & 62.7 & $2.89 \mathrm{~m}$ & 62.8 & $2.94 \mathrm{~m}$ \\
\hline $7_{\text {pseudoequatorial }}$ & 35.3 & $3.07 \mathrm{~m}$ & 35.9 & $3.05 m$ & 35.1 & $3.05 \mathrm{~m}$ \\
\hline 7 pseudoaxial & & $2.48 \mathrm{~m}$ & & $2.46 \mathrm{~m}$ & & $2.52 \mathrm{~m}$ \\
\hline $7 \mathrm{a}$ & 120.1 & & 130.2 & & 129.7 & \\
\hline 8 & 111.0 & $6.83 s$ & 119.0 & $6.82 d(8.1)$ & 119.3 & $6.84 d(8.1)$ \\
\hline 9 & 149.5 & & 111.2 & $6.86 d(8.1)$ & 111.3 & $6.86 d(8.1)$ \\
\hline 10 & 144.0 & & 148.5 & & 149.1 & \\
\hline 11 & 117.5 & $8.80 s$ & 144.2 & & 143.7 & \\
\hline $11 \mathrm{a}$ & 129.5 & & 120.2 & & 119.7 & \\
\hline $\mathrm{H}_{3} \mathrm{C}-\mathrm{N}$ & 43.9 & $2.54 s$ & 43.8 & $2.55 s$ & 43.6 & $2.57 s$ \\
\hline $\mathrm{H}_{3} \mathrm{CO}-1$ & 56.1 & $3.90 s$ & & & 62.3 & $3.62 s$ \\
\hline $\mathrm{H}_{3} \mathrm{CO}-2$ & 56.0 & $3.90 \mathrm{~s}$ & & & & \\
\hline $\mathrm{H}_{3} \mathrm{CO}-10$ & 56.3 & $3.92 s$ & 56.2 & $3.91 s$ & 56.3 & $3.92 s$ \\
\hline $1-\mathrm{OCH}_{2} \mathrm{O}-2$ & & & 100.3 & $\begin{array}{l}6.10 d(1.4) \\
5.95 d(1.4)\end{array}$ & & \\
\hline
\end{tabular}

${ }^{\mathrm{a} N M R}$ experiments were acquired at $303 \mathrm{~K}$ with TMS as internal reference at $0.00 \mathrm{ppm}$ in $\mathrm{CDCl}_{3} .{ }^{\mathrm{b}}$ Multiplicities determined by DEPT 135 , $\mathrm{HSQC}$ and $\mathrm{HMBC}$ experiments. $\mathrm{NO}=$ no observed.
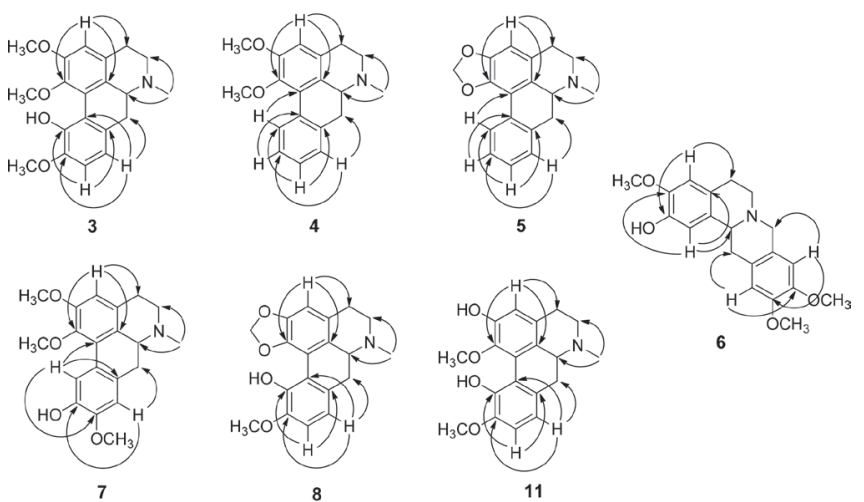

Figure 2. Key correlations observed in HMBC (arrows) of alkaloids 3-8 and $\mathbf{1 1}$

for leukemia (HL-60). Doxorubicin, used as positive control, showed $\mathrm{IC}_{50}$ values ranging from 0.39 to $1.29 \mu \mathrm{mol} \mathrm{L}{ }^{-1}$ for tumor cell lines, and a selectivity index of 3.7 for the same tumor cell line (HL-60).

\section{CONCLUSIONS}

The phytochemical study of G. pogonopus displayed a structural diversity of alkaloids its leaves, which contributes to the chemotaxonomic knowledge of the genus Guatteria. Compounds 6-8 and $\mathbf{1 1}$ are reported for the first time in Annonaceae and 1,2,9-trimethoxy-10-hydroxyaporphine (7) is reported for the first time as a natural product. Significant cytotoxic activities recorded against human tumor cell lines have demonstrated that this species is a natural source of biologically active compounds. Strong activity against human promyelocytic leukemia (HL-60) was observed to the oxoaporphine alkaloid liriodenine (9) in a mixture with tetrahydropseudocolumbamine (6) and lysicamine (10).

\section{SUPPLEMENTARY MATERIAL}

Supplementary material containing 1D and 2D NMR data of the alkaloids isolated of the leaves of G. pogonopus are available free of charge at http://jbcs.sbq.org.br as a PDF file.

\section{ACKNOWLEDGEMENTS}

The authors are grateful to CNPq, CAPES, FINEP, FAPEAM, Fundação Araucária, FAPITEC/SE, UFAM, UFS, and UFPR for financial support and fellowship. 
Table 4. Cytotoxic activities of the alkaloids from leaves of Guatteria pogonopus

\begin{tabular}{|c|c|c|c|c|c|}
\hline \multirow{2}{*}{ Alkaloids } & \multicolumn{5}{|c|}{$\mathrm{IC}_{50}$ in $\mu \mathrm{mol} \mathrm{L}-1$} \\
\hline & B16-F10 & HepG2 & HL-60 & K562 & PBMC \\
\hline (+)-nornuciferine (1) & $\begin{array}{c}35.05 \\
25.38-48.38\end{array}$ & $\begin{array}{c}9.60 \\
5.87-15.68\end{array}$ & $\begin{array}{c}13.97 \\
8.28-23.57\end{array}$ & $\begin{array}{c}15.28 \\
11.02-21.21\end{array}$ & $\begin{array}{c}37.50 \\
28.90-48.66\end{array}$ \\
\hline$(+)$-isocorydine (3) & $\begin{array}{c}51.08 \\
29.26-89.19\end{array}$ & $\begin{array}{c}25.37 \\
14.18-45.41\end{array}$ & $\begin{array}{c}43.61 \\
24.16-78.69\end{array}$ & $\begin{array}{c}17.13 \\
10.69-27.47\end{array}$ & $\begin{array}{c}49.47 \\
37.52-65.29\end{array}$ \\
\hline (+)-nuciferine (4) & $\begin{array}{c}19.91 \\
17.47-22.72\end{array}$ & $\begin{array}{c}22.65 \\
19.03-26.95\end{array}$ & $\begin{array}{c}22.92 \\
18.55-35.01\end{array}$ & $\begin{array}{c}39.71 \\
34.73-45.43\end{array}$ & $\begin{array}{c}45.30 \\
30.49-66.63\end{array}$ \\
\hline (+)-roemerine (5) & $\begin{array}{c}27.42 \\
22.91-32.67\end{array}$ & $\begin{array}{c}26.31 \\
20.08-34.47\end{array}$ & $\begin{array}{c}28.53 \\
22.84-35.58\end{array}$ & $\begin{array}{c}45.18 \\
37.73-54.13\end{array}$ & $\begin{array}{c}59.21 \\
41.92-83.66\end{array}$ \\
\hline (-)-tetrahydropseudocolumbamine (6) & $>73.23$ & $>73.23$ & $>73.23$ & $>73.23$ & $>73.23$ \\
\hline 1,2,9-trimethoxy-10-hydroxyaporphine (7) + bulbocapnine (8) & $>36.72$ & $>36.72$ & $>36.72$ & $>36.72$ & $>36.72$ \\
\hline $\begin{array}{l}\text { (-)-tetrahydropseudocolumbamine }(\mathbf{6})+\text { liriodenine }(\mathbf{9})+ \\
\text { lysicamine (10) }\end{array}$ & $\begin{array}{c}16.33 \\
13.48-19.78\end{array}$ & $\begin{array}{c}19.75 \\
15.64-24.94\end{array}$ & $\begin{array}{c}3.41 \\
2.30-5.05\end{array}$ & $\begin{array}{c}8.50 \\
4.88-14.83\end{array}$ & $\begin{array}{c}33.34 \\
29.13-38.14\end{array}$ \\
\hline (+)-N-methyllindicarpine (11) & $>76.36$ & $>76.36$ & $>76.36$ & $>76.36$ & $>76.36$ \\
\hline Doxorubicin & $\begin{array}{c}1.12 \\
0.94-1.32\end{array}$ & $\begin{array}{c}0.64 \\
0.51-0.81\end{array}$ & $\begin{array}{c}0.39 \\
0.26-0.58\end{array}$ & $\begin{array}{c}1.29 \\
0.98-1.73\end{array}$ & $\begin{array}{c}1.42 \\
0.79-2.58\end{array}$ \\
\hline
\end{tabular}

Data are presented as $\mathrm{IC}_{50}$ values, in $\mu \mathrm{mol} \mathrm{\textrm {L } ^ { - 1 }}$, and their $95 \%$ confidence interval obtained by nonlinear regression from three independent experiments performed in duplicate, measured using alamar blue assay after $72 \mathrm{~h}$ incubation. Tumor cells: B16-F10 (mouse melanoma), HepG2 (human hepatocellular carcinoma), HL-60 (human promyelocytic leukemia) and K562 (human chronic myelocytic leukemia). Non-tumor cell: PBMC (human peripheral blood mononuclear cells activated with concanavalin A - human lymphoblast). Doxorubicin was used as positive control.

\section{REFERENCES}

1. Erkens, R. H. J.; Chatrou, L. W.; Maas, J. W.; Niet Timotheu, S. V. D., Savolainen, V.; Mol. Phylogenet. Evol. 2007, 44, 399.

2. Lobão, A. Q.; Mello-Silva, R.; Forzza, R. C.; Rodriguésia 2012, 63, 1039.

3. Fontes, J. E. N.; Ferraz, R. P.; Britto, A. C.; Carvalho, A. A.; Moraes, M. O.; Pessoa, C.; Costa, E. V.; Bezerra, D. P.; Chem. Biodiversity 2013, 10, 722.

4. Meira, C. S.; Menezes, L. R. A.; Santos, T. B.; Macedo, T. S.; Fontes, J. E. N.; Costa, E. V.; Pinheiro, M. L. B.; Silva, T. B, Guimarães, E. T.; Soares, M. B. P.; J. Essent. Oil Res. 2017, 29, 156.

5. Britto, A. C. S.; Oliveira, A. C. A.; Henriques, R. M.; Cardoso, G. M. B.; Bonfim, D. S.; Carvalho, A. A.; Moraes, M. O.; Pessoa, C.; Pinheiro, M. L. B.; Costa, E. V.; Bezerra, D. P.; Planta Med. 2012; 78, 409.

6. Ferreira, C.; Passos, C. L. A.; Soares, D. C.; Costa, K. P.; Rezende, M. J. C.; Lobão, A. Q.; Pinto, A. C.; Hamerski, E. M.; Exp. Parasitol. 2017, $172,51$.

7. Costa, E.V.; Pinheiro, M. L.; Barison, A.; Campos, F.; Salvador, M. J.; Maia. B. H.; Cabral, E. C.; Eberlin, M. N.; J. Nat. Prod. 2010, 25, 1180.

8. Santos, M. F. C.; Dutra, L. M.; Moraes, V. R. S.; Barison, A.; Costa, E. V.; Biochem. Syst. Ecol. 2015, 60, 106.

9. Dutra, L. M.; Costa. E. V.; Moraes, V. R. S.; Nogueira, P. C. L.; Vendramin, M. E.; Barison, A.; Prata, A. P. N.; Biochem. Syst. Ecol. 2012, 41, 115.

10. Costa, E. V.; Sampaio, M. F. C.; Salvador, M. J.; Nepel, A.; Barison, A.; Quim. Nova 2015, 38, 769.

11. Chen, C.-Y.; Chang, F.-R.; Wu, Y.-C.; J. Chin. Chem. 1997, 44, 313. Teles, M. N. O.; Dutra, L. M.; Barison, A.; Costa, E. V. Biochem. Syst. Ecol. 2015, 61, 465.

12. Costa, E. V.; Marques, F. A.; Pinheiro, M. L. B.; Vaz, N. P.; Duarte, M. C. T.; Delarmelina, C.; Braga, R. M.; Maia, B. H. L. N. S.; J. Nat. Prod. 2009, 72, 1516.

13. Harrigan, G. G.; Gunatilaka, A. A.; Kingston, D. G.; Chan, G. W.; Johnson, R. K.; J. Nat. Prod. 1994, 57, 68; Costa, E. V.; Pinheiro, M. L. B.; Souza, A. D. L.; Barison, A.; Campos, F. R.; Valdez, R. H.; Ueda-
Nakamura, T.; Dias Filho, B. P.; Nakamura, C. V. Molecules 2011, 16, 9714.

14. Ahmed, S. A.; Gogal, R. M.; Walsh, J. E.; J. Immunol. Methods, 1994, 170, 211.

15. Zhenjia, Z.; Minglin, W.; Daijie, W.; Wenjuan, D.; Xiao, W.; Chengcha, Z.; J. Chromatogr. B 2010, 878, 1647.

16. Moulis, C.; Stanislas, E.; Rossi, J. C.; Org. Magn. Reson. 1978, 11, 398.

17. Ohiri, F. C.; Verpoorte, R.; Svendsen, A. B.; Planta Med. 1983, 49, 17.

18. Hara, H.; Hoshino, O.; Umezawa, B.; Chem. Pharm. Bull. 1975, 8, 1921.

19. Baarschers, W. H.; Arndt, R. R.; Tetrahedron, 1965, 21, 2155.

20. Wet, H.; Heerden, F. R.; Wyk, B.-E.; Biochem. Syst. Ecol. 2005, 33, 799.

21. Johns, S. R.; Lamberton, J. A.; Aust. J. Chem. 1967, 20, 1277.

22. Lopez, J. A.; Laurito, J. G.; Brenes, A. M.; Lin, F. T.; Sharaf, M.; Wong, L. K.; Schiff Jr., P. L.; Phytochemistry 1990, 29, 1899.

23. Leboeuf, M.; Cave, A. F.; Plantes Med. Phytother. 1972, 6, 87.

24. Tran, D. T.; Mai, H. D. T.; Pham, V. C.; Nguyen, V. H.; Litaudon, M.; Gueritte, F.; Nguyen, Q. V.; Tran, T. A.; Chau, V. M.; Phytochem. Lett. 2013, 6, 79 .

25. Cortes, D.; Hocquemiller, R.; Leboeuf, M.; Cave, A.; Moretti, C. J. Nat. Prod. 1986, 49, 878.

26. Rasamizafy, S.; Hocquemiller, R.; Cave, A.; Jacquemin, H.; J. Nat. Prod. 1986, 49, 1078.

27. Menezes, L. R.; Costa, C. O.; Rodrigues, A. C.; Santos, F. R.; Nepel, A.; Dutra, L. M.; Silva, F. M.; Soares, M. B.; Barison, A.; Costa, E. V.; Bezerra, D. P.; Molecules 2016, 21, 890.

28. Shafiee, A.; Ghanbarpour, A.; Lalezari, I.; Lajevardi, S.; J. Nat. Prod. 1979, $42,174$.

29. Sun, R., Jiang, H.; Zhang, W.; Yang, K.; Wang, C.; Fan, L.; He, Q.; Feng, J.; Du, S.; Deng, Z.; Geng, Z.; J. Evidence-Based Complementary Altern. Med. 2014, 580, 483.

30. Duan, X. H., Pei, L., Jiang, J. Q.; Zhongguo Zhong Yao Za Zhi 2013, 38 , 4104.

31. Costa, E. V.; Pinheiro, M. L.; Maia, B. H.; Marques, F. A.; Ruiz, A. L.; Marchetti, G. M.; Carvalho, J. E.; Soares, M. B.; Costa, C. O.; Galvão, A. F.; Lopes, N. P.; Koolen, H. H.; Bezerra, D. P.; Barison, A.; J. Nat. Prod. 2016, 79, 1524. 